\title{
The Framing of Russian Military Involvement in the Syrian Civil War on Sputnik Media
}

\author{
$1^{\text {st }}$ Khairuni Cesario \\ Russian Studies Program, Faculty of \\ Humanities \\ Universitas Indonesia \\ Depok, Indonesia \\ khairuni.cesario@ui.ac.id
}

\author{
$2^{\text {nd }}$ Reynaldo de Archellie* \\ Department of Area Studies, Faculty of \\ Humanities \\ Universitas Indonesia \\ Depok, Indonesia \\ reynaldo.de@ui.ac.id
}

\begin{abstract}
The legitimacy of a country's foreign policy is often determined by how the media report on the country's political activity outside that country. The country's involvement in a conflict or war and the reason for engaging needs to be communicated to the public globally with a mediaframing strategically. This article aims to explore the framing of the Russian military's involvement in the Syrian civil war by the online media outlet Sputnik. The researchers employed a qualitative content analysis method on 238 articles published by Sputnik between February and September 2016. During this period Russia and the United States, as two external powers involved in the Syrian civil war, agreed on a ceasefire. This development represented a strategic moment for Russia to communicate the activities of its military in Syria by using a framing strategy in Sputnik. This research revealed that Sputnik actively used framing to legitimize the Russian military's involvement in the Syrian civil war. Specifically, the media outlet used the frames of responsibility, morality, and conflict to attract public attention and to shape their perspectives about the Russian military's involvement in the Syrian civil war as necessary and positive. The findings indicate that, at Sputnik, framing constituted an attempt to form a positive image of Russia as a strong state to the international world through news related to the involvement of the Russian military in Syria's civil war.
\end{abstract}

Keywords_Framing; Media; Russian Military; Syrian Civil War; Sputnik

\section{Introduction}

The media functions as one means for the Russian government to maintain its political power and protect the government from public criticism from the time of the Tsar governments to the Soviet era [1], [2]. After the collapse of the Soviet Union, the oligarchs ruled the media [3]. Subsequently, the government of President Vladimir Putin took over the media, which was considered important to maintain under state supervision. The government applied intense political pressure, resulting in changes in leadership at several media outlets [4]. State intervention in the media has strengthened, especially after the Crimean crisis, with the aim of maintaining the sustainability of the government and national security [5]. It is also an attempt to control the media. The media is considered very important because it can shape the public perception of an issue [5].

The media is a source of information about conflict and war. Only a few people have the ability, time, and interest necessary to observe and report on the causes and consequences of a conflict. Thus, people use the media to find information and understand conflicts [6], and the media influences the way the public thinks about an issue [7]. Framing is a very important way of informing people located far from conflict zones [6].

Framing requires messages that are selectively targeted toward an issue, candidate, product, or service. Framing can be used to arrange the way people think about the choices and alternative actions used to achieve certain goals. Framing can also be used to benefit certain parties and attribute the responsibility for actions, issues, or social problems. In addition, in the news, framing is an important process used to recount an event that has relevance and meaning for the public [8].

Framing is no stranger to Russian media, and the Russian government has used it to control the media. Control over the media is also part of the government's censorship policy, which affects the attitudes in Russian society toward the Internet, as well as confidence in the reliability of digital content [4]. Framing can lead to manipulation of the media [9], and political actors may even encourage media outlets to frame issues in a particular way [10]. An example of such a framing is the Russia Today coverage of the negative side of the United States military during the 2014 Russian financial crisis, which was used to divert public attention from one issue to another [9].

Framing was also applied in Russian media outlets during the Crimean problem. Russian media outlets frame the Crimean problem as reunification, whereas the United States media presents the Crimean problem as an annexation. Thus, framing can display problems from different sides, and it can also highlight certain political interests, the media system, journalists' norms, as well as the cultural and historical roots of an issue [11].

Another case frequently reported in the media is the issue of the Syrian civil war. This conflict has become an issue in international politics. Moreover, during this conflict, very alarming information about a dangerous terrorist group called ISIS began to spread [12]. As Russia is one of the external parties that has played an important role in this conflict, various media outlets have reported on Russia's involvement in the Syrian civil war. However, each media organization has a different reporting method. The question posed in this article is how framing is used in Sputnik regarding Russian military involvement in the Syrian civil war.

For the literature review in this article, several papers were analyzed. The first article, from 2018, is entitled 
"Framing in Russian TV News: How to Shape Reality?" written by Galina Lukyanova [13]. Lukyanova analyzed the reflection of a particular political event in the media by applying various theoretical frameworks to understand framing and content analysis methods. According to Lukyanova [13], framing is actively used by the main TV channels as a tool to legitimize power. Lukyanova [13] examined the Pervyi and Russia-1 channels as the most popular TV channels for Russian people. He found that most of the news focused on the political and nonpolitical activities of the Russian president. He identified the form's frame, which creates framing in the media and was used at both TV channels. This framing also has an impact on the public. In addition, Lukyanova [13] found that both TV channels framed the issue in the same way, resulting in a greater impact.

Next, the second work analyzed for the literature review in this article is a 2012 thesis entitled "The New York Times' Framing of the Involvement of the Russian Federation in Arms and Nuclear Trade with the Islamic Republic of Iran in 2009-2011" written by Artem Bagiev [14]. Bagiev's thesis focuses on framing in The New York Times regarding the involvement of Russia and Iran in the nuclear and weapons trade from 2009 to 2011. He applied various theoretical frameworks to understand framing and content analysis methods. According to Bagiev [14], framing in The New York Times can be seen by identifying complex processes in deciding the content, facts, context, and language selection in a story. He used three forms of frame based on the work of Semetko and Valkenburg, namely responsibility [15], conflict, and economy. According to Bagiev [14], the analysis of these three frames demonstrated how The New York Times covered this issue.

The final source is a 2016 thesis entitled "Crimean Referendum 2014: Annexation versus Reunification. Framing Analysis of Online News Coverage in Russia and the US" written by Anna Dedova [11]. He compared the difference in framing between two different news sources, Kommersant and The New York Times. He also used various theoretical frameworks to understand framing and content analysis methods. According to Dedova [11], the framing of the two media reveals certain political interests, the media system, journalists' norms, and the cultural and historical roots of the Crimean referendum issue.

Some researchers have also discussed Russia's involvement in the Syrian civil war [16], [12]. However, previous studies did not specifically address Russian military involvement or link the topic to the use of framing by the media. The main focus of this article is to look at Sputnik's use of framing regarding Russia's military involvement in the Syrian civil war. In essence, this article aims to contribute to the scientific discussion that media outlets are agents that can shape or change identities.

This article uses the content analysis method with Entman's framing concept. According to him, framing takes place through the selection and highlighting of certain aspects [17]. Furthermore, the deductive approach was used to analyze framing in Sputnik by using a frame that has been defined and applied in previous studies (Vresee, 2005) [18]. Furthermore, the frames were identified based on the frame form as defined by Semetko and Valkenburg [15] — namely the responsibility, morality, conflict, economic, and human interest frames.

\section{Method}

This research features a qualitative approach with a content analysis method. Qualitative research is an approach to understanding an individual or group of people involved in social or humanitarian issues [19]. Qualitative research relies on text and image data, and it also consists of unique steps for analyzing data and has diverse models [19].

The content analysis method is very efficient for investigating printed media content in the form of a broadcast [21]. Qualitative content analysis is not only able to identify the manifest messages but also latent messages from a document under study. Qualitative content analysis allowed the authors of this paper to understand media content more deeply and relate it to the social context or reality that exists [21].

Qualitative research featuring the content analysis method is subjective, as well as explanatory or exploratory [22]. Qualitative content analysis refers to an integrative and more conceptual analysis method for finding, identifying, processing, and analyzing documents to understand their meaning, significance, and relevance [21].

According to Manzilati [22], Sarantakos proposed the stages in the process of content analysis using the qualitative paradigm applied in this study, as explained in the following section.

\section{Summary}

The first stage involves the reduction, integration, generalization, and classification of data in several specific categories. The data used in this study come from a collection of news from the Sputnik website, sputniknews.com [23]. As a first step, the writer used a search engine and sought out news using the keyword phrase "Russian Military in Syrian Civil War." Afterward, the writer classified each of the news pieces based on the period and the broader theme.

The reason for choosing Sputnik was because of Russia's goal of launching Sputnik in 2014 as an instrument against Western media [24]. Sputnik publishes news in 30 languages and forms a self-image as a source of alternative news content that is far more explicit about propaganda messages than the other Russian media source, Russia Today [25]. The formation of Sputnik was not only due to Russia Today losing its credibility among the U.S. audience during the Ukraine crisis but also because Russia understood that a new form of communication was needed [26], [24].

The data collection was limited to two ceasefire periods agreed upon by Russia and the United States, two external forces that have played an important role in Syria's civil war. Period I is the first ceasefire agreement between Russia and the United States from February 22 to July 30, 2016; period II is the second ceasefire agreement between Russia and the United States from September 9-19, 2016. The second ceasefire occurred because the first ceasefire was deemed ineffective due to violations of the agreement, as evidenced by the increasing number of attacks in July 2016 [27]. 


\section{Explication}

This phase describes the results of a summary. Data that have been classified are explained at this stage.

\section{Structuration}

This is the stage of restructuring the data based on existing criteria to form meaning. Data that have been classified and explained are reorganized to form a meaning.

\section{Objective Hermeneutics}

The stage of meaning is known as the latent structure of meaning. The authors of this article used Entman's concept of framing to interpret data that had been previously classified. According to Entman [17], framing consists of two important processes, namely the selection and highlighting of certain aspects, as seen through the formation of a frame, which is based on data that have been. The frame in this research was formed using a deductive approach based on the form of the frame defined by Semetko and Valkenburg [15].

\section{Results and Discussion}

According to the "About Us" feature on its website, Sputnik is a news agency that not only releases news but also manages sites, social networks, applications, radio, and multimedia press centers. Sputnik covers world economic and political news, targeting an international audience. At present, Sputnik's editorial staff works in more than 30 languages, including English, Chinese, Spanish, French, German, Arabic, and others.

Search results from the Sputnik page produced 238 articles. These data were obtained by typing the keyword "Russian Military in Syrian Civil War" and setting the time period in the Sputnik site search column. Period I is the first ceasefire agreement between Russia and the United States from February 22 to July 30, 2016; period II is the second ceasefire agreement between Russia and the United States in the period September 9-19, 2016.

\begin{tabular}{|l|l|}
\hline \multicolumn{1}{|c|}{ Time } & \multicolumn{1}{c|}{ Total } \\
\hline Period I & 75 \\
\hline Period I & 17 \\
\hline Total & 238 \\
\hline
\end{tabular}

The articles were divided into 16 different categories, but several articles in periods I and II have links to each other in terms of their subject matter regarding the importance of Russia's role in Syria and the eradication of terrorists. For example, an article discussing the importance of Russia's role in the Syrian conflict in period I first appeared on February 22, 2016, under the title "Syrian Ceasefire: Why Situation May 'Spin Out of Control'," which discusses Russia's role as the only country that can help Syria. The article falls into the "Middle East" category. This article is then supported by other articles with the same theme in different categories: an article with the title "Putin Praises Russia's Security Service for Anti-Terrorist Work in Syria" in the "Russia" category, an article entitled "West Should Work With Russia to Ensure
Syrian Settlement-US Analyst" in the "US" category and in other categories that reinforce "Russia's Important Role in Syria."

In addition to Russia's important role in Syria and the eradication of terrorism, a topic frequently discussed in the articles selected is the success of the Syrian army in defeating terrorists and assistance for Syria, which was successfully supported by the Russian military. An article discussing Syrian assistance that was successfully orchestrated by the Russian military first appeared with the title "Russian Military Helps to Deliver Food to Syrian Deir ez-Zor" on April, 7, 2016, in the "Middle East" category and was also supported by the appearance of articles in the categories "Politics," "Asia and Pacific," and "World" that discuss the same ideas.

Moreover, articles published in Sputnik [23] provide a positive picture of Russia as a powerful country that has an important role in Syria and supports the Syrian government. Examples include articles discussing the success of the Syrian army in eradicating terrorists with Russian military assistance. Other articles discuss certain figures who support Russia's involvement in the Syrian conflict. It can be said that all articles relating to the involvement of Russia or the Russian military paint a positive picture compared to articles about the involvement of the United States, which attend to be negative.

Based on these results, there are four main topics discussed in Sputnik: 1) Russia's role in Syria, 2) eradicating terrorists, 3) the success of the Syrian army in conquering terrorists, and 4) the Russian military successes in delivering aid to Syria. As defined earlier in this paper, framing is the selection of several aspects of reality that are highlighted in a text. Framing involves two important processes, namely the selection and highlighting of certain aspects. Thus, it is necessary to form a certain frame. The four main topics are aspects that are considered important in forming a frame in the delivery.

Framing in the media can be identified by using five forms of frames: the responsibility, conflict, morality, economic, and human interest frames [14]. Sputnik only uses three forms of frames related to four topics that are considered important aspects. The three forms frames used are those of responsibility, morality, and conflict.

First, the most commonly applied frame among the four main topics is the frame of responsibility. This frame displays events in such a way as to link the responsibilities of individuals, groups, or governments in causing or resolving a problem [14]. In accordance with its definition of framing, Sputnik uses frames to report on Russia's important role in the Syrian conflict. The success of the Syrian army has always been linked to assistance from the Russian military. Instead, the United States is depicted as one of the causes of problems in Syria by providing support to Syrian antigovernment groups.

In several articles, the use of the frame of responsibility shows Russia's strong position in political matters, which is indicated by the news regarding the Syrian government's dependence on Russia. Furthermore, frame is also employed to denounce the actions taken by the United States in the Syrian civil war. This frame also appears in almost all 
Sputnik news categories and is also used in conjunction with other frames.

As already mentioned, the frame of responsibility became the most dominant one used regarding Russian military involvement in the Syrian civil war. This frame forms part of the process of highlighting important aspects. The prominence of this important aspect is characterized as making information more visible, meaningful, and impressive to the public [16]. The use of the frame of responsibility can be interpreted in order to influence the public. The use of the frame also increases the likelihood that the public will remember information regarding Russian military involvement in the Syrian civil war. This frame can also be interpreted to emphasize the importance of the Russian military presence in Syria.

Secondly, the frame of morality is another commonly used frame that places events in the context of religious or moral principles [14]. Related to the said frame, Sputnik put the increased involvement of the Russian military in the Syrian civil war in a moral context. The Russian military is portrayed as a hero in the Syrian civil war. This type of reporting can be seen in the news about humanitarian aid that was successfully sent by the Russian military. It was also strengthened by news stories discussing the success of the Syrian army in eradicating terrorist groups with Russian military assistance.

Third, there is the use of the frame of conflicts. This frame is not used much. The frame of conflict itself is a frame that emphasizes conflict between individuals, groups, or institutions with the aim of attracting public attention [14]. Although this frame was not widely used, some reports in Sputnik feature attacks carried out by terrorist groups supported by the United States. One article also includes a discussion related to World War II, stating that the United States illegally attacked an independent country. In fact, according to that article, Russia has tried to follow existing regulations after World War II by enforcing international law. This frame confirms that the dangerous actions in the Syrian civil war came from terrorist groups supported by the United States.

The use of three frames in the Sputnik media regarding Russian military involvement in the Syrian civil war also has a specific purpose. A frame shows the problem's definition, explanation, evaluation, and solutions [16]. First, Sputnik defined the problem of Russian military involvement in the Syrian civil war as assistance provided by the Russian government to the Syrian government to fight terrorist groups that oppose the government. This idea is communicated through the use of the frames of responsibility and morality. Second, in this case, the cause or source of the problem is always associated with terrorist attacks or actions taken by the United States in Syria through the frames of responsibility or conflict. Third, the evaluation occurs through the use of the frame of morality, which depicts the involvement of the Russian military in Syria as a positive development. Fourth, the problemsolving recommendations emphasized can be achieved by the Syrian government with assistance from Russia to eradicate terrorism in Syria through the frame of responsibility.

\section{Conclusions}

Based on the analysis in this research, it can be concluded that framing is actively used by Sputnik as a tool to legitimize foreign policy and the actions of the Russian government in the Syrian civil war, as indicated by the use of three forms of frames, namely those of responsibility, morality, and conflict. The three frames justify the government's actions and present them as aid that plays a large role in the Syrian conflict. The third frame is also used to attract public attention. The use of the frame is expected to make the public remember more information about how Russia has an important role in the Syrian conflict. The third frame also shows that framing is used to make the public think that Russia's military involvement constitutes a positive Russian effort in helping to resolve the conflict in Syria.

Sputnik itself also aims its site toward an international audience. Framing on the site represents an effort to form a positive image of Russia to the international world-Russia as a powerful country that has a large role in the Middle East, especially in the Syrian civil war. The use of frames is dominant and furthers Sputnik's goal of shaping a positive Russian image. Framing prioritizes the positive impact of Russia's decision to involve its military in the Syrian civil war while criticizing the actions taken by the United States in the conflict. Through this lens, media consumers learn that the United States is a party that has a fairly strong position in the Syrian civil war, stories framed in such ways greatly strengthen Russia's positive image as a powerful country with a large influence on the Syrian civil war.

\section{References}

[1] Lipman, M. (2005). Constrained or Irrelevant: The Media in Putin's Russia. Current History, 319-324.

[2] Ruud, C. (2009). Fighting Words: Imperial Censorship and the Russian Press. Toronto: University of Toronto Press.

[3] Zassourky, I. (1999). Mass Media of the Second Republic. Moscow: MGU. Panorama.

[4] Ogyanova, K. (2010). Careful What You Say: Media Control in Putin's Russia - Implications for Online Content. International Journal of EPolitics, 1-15.

[5] Simons, G. (2015). Russian Media and Censorship: A Means or an End? Russian Journal of Communication, Volume 7, 300-312.

[6] Somerville, K. (2017). Framing Conflict - The Cold War and after: Reflections from an Old Hack. Media, War \& Conflict, Volume 10 $48-58$

[7] Besova, A. A., \& Cooley, S. C. (2009). Foreign News and Public Opinion: Attribute Agenda-Setting Theory Revisited. Ecquid Novi: African Journalism Studies, Volume 30, 219-242.

[8] Hallahan, K. (1999). Seven Models of Framing: Implications for Public Relations. Journal of Public Relations Research, Volume 11, $205-$ 242.

[9] Field, A., Kliger, D., Wintner, S., Pan, J., Jurafsky, D., \& Tsvetkov, Y. (2018). Framing and Agenda-Setting in Russian News: A Computational Analysis of Intricate Political Strategies. The 2018 Conference on Empirical Methods in Natural Language Processing (pp. 3570-3580). Brussels: Association for Computational Linguistics.

[10] Fridkin, K., \& Kenny, P. (2005). Campaign Frames: Can Candidates Influence Media Coverage. In Framing American Politics K. Callaghan, \& F. Schnell (pp. 54-75). Pittsburg: University of Pittsburg Press.

[11] Dedova, A. (2016). Crimean Referendum: Annexation VS Reunification. Framing Analysis of Online News Coverage in Russia and the U.S. Tampa: University of South Florida.

[12] Rahman, S. (2016). Syrian Civil War: A Historical Study from the Russian Perspectives. International Journal of Humanities Social Sciences \& Education, 7-13. 
[13] Lukyanova, G. (2018). Framing in Russian TV News: How to Shape Reality? SHS Web of Conferences, Volume 50.

[14] Bagiev, A. (2012). The New York Times' Framing of Involvement of the Russian Federation in Arms and Nuclear Trade with the Islamic Republic of Iran in 2009-2011. Lawrence: University of Kansas.

[15] Semetko, H. A., \& Valkenburg, P. M. V. (2000). Framing European Politics: A Content Analysis of Press and Television News. Journal of Communication, Volume 50, 93-109.

[16] Kozhanov, N. (2016). Russia and the Syrian Conflict: Moscow's Domestic, Regional. Berlin: Gerhald Press.

[17] Entman, R. M. (1993). Framing: Toward Clarification of a Fractured Paradigm. Journal of Communication, Volume 43, 51-58.

[18] Vreese, C. D. (2005). News Framing: Theory and Typology. Information Design Journal, 51-62.

[19] Creswell, J. (2013). Qualitative Inquiry \& Research Design: Choosing among Five Approaches (3rd ed.). CA: SAGE.

[20] Bungin, B. (2012). Penelitian Kualitatif. Komunikasi, Ekonomi, KebijakanPublik, dan Ilmu Sosial lainnya. Jakarta: Kencana.

[21] Manzilati, A. (2017). Metode Penelitian Kualitatif: Paradigma, Metode dan Aplikasi. Universitas Brawijaya Press.
[22] Sputnik (2019, April 8). About Us: Retrieved from https://sputniknewsSputniknews.com/docs/about/index.html.

[23] Jaitner, M., \& Mattson, P. (2015). Russian Information Warfare of 2014. The 7th International Conference on Cyber Conflict. Tallin.

[24] Boffey, D., \& Rankin, J. (2017). EU Escalates Its Campaign against Russian Propaganda. Retrieved from The Guardian: Retrieved from http://www.theguardian.com/world/2017/jan/23/eu-escalatescampaign-russian-propaganda.

[25] Snegovaya, M. (2015). Putin's information warfare in Ukraine (Russia Report no. 1): Retrieved from

http://www.understandingwar.org/sites/default/files/Russian\%20Re port $\% 201 \% 20$ Putin $\% 27 \mathrm{~s} \% 20$ Information $\% 20$ Warfare $\% 20$ in $\% 20 \mathrm{U}$ kraine-

$\% 20$ Soviet $\% 20$ Origins $\% 20$ of $\% 20$ Russias $\% 20$ Hybrid\%20Warfare.p df. Retrieved from The Institute for the study of war.

[26] Heinrich, M. (2016, Juli 6). Syrian Army, Rebels Agree to 72-Hour Eid Truce, but Fighting Continues. Retrieved from Reuters: Retrieved from https://www.reuters.com/article/us-mideast-crisissyria-truce-idUSKCNOZMOPZ. 